\title{
STRATEGI MEDIA MNC GROUP DAN KOMPAS GRAMEDIA GROUP DALAM MENGHADAPI SISTEM STASIUN JARINGAN DI KOTA SEMARANG
}

\author{
Joko Adi Purnomo \\ Magister Ilmu Komunikasi Undip \\ jackoale3@gmail.com
}

\begin{abstract}
Abstrak
Derasnya perkembangan dunia pertelevisian perlu adanya peraturan yang tegas untuk mengaturnya. Seperti disampaikan Firman Subagyo, Wakil Ketua Baleg DPR RI dalam acara diskusi tentang UU Penyiaran; "Sudah 15 tahun UU Penyiaran ini disahkan oleh DPR, namun hingga saat ini implementasi UU tersebut, khususnya tentang keharusan bagi stasiun televisi yang bersiaran secara nasional untuk berjaringan di daerah tidak terimplementasikan".Tulisan ini bertujuan mengargumentasikan peran UU Penyiaran dalam strategi media MNC group dan Kompas Gramedaia dalam menghadapi sistem stasiun jaringan di kota Semarang. Dengan menggunakan sudut pandang kritis dari studi aspek kebijakan media, diargumentasikan untuk menjelaskan strategi media MNC Group dan Kompas Gramedia dalam menghadapi sistem stasiun jaringan di kota Semarang mengenai membuat keputusan mengenai sasaran dan tujuan program penyiaran, melakukan identifikasi dan sasaran (target) audien, menetapkan kebijakan atau aturan untuk menentukan strategi yang akan dipilih, memutuskan strategi yang akan digunakan, pada stasiun televisi perencanaan strategis sangat diperlukan agar tujuan dari perencanaan penyiaran bisa tercapai. Pada akhirnya diperlukan kajian yang lebih mendalam baik dari aspek empiris maupun aspek literatur untuk mengetahui lebih jauh mengenai strategi media dalam menghadapi sistem stasiun jaringan.
\end{abstract}

Kata kunci : Kebijakan Media, Teori Kritis, Stasiun TV Jaringan

\begin{abstract}
The rapid development of television requires strict regulations to regulate it. As stated by Firman Subagyo, Deputy Chairperson of the DPR RI Baleg in a discussion on the Broadcasting Law; "It has been 15 years since the Law on Broadcasting was passed by the DPR, but until now the implementation of the Law, especially regarding the obligation for national broadcasting television stations to network in the regions has not been implemented." This paper aims to argue for the role of the Broadcasting Law in the MNC group's media strategy and Kompas Gramedaia in dealing with the network station system in the city of Semarang. By using a critical point of view from a study of aspects of media policy, it is argued to explain the media strategy of MNC Group and Kompas Gramedia in dealing with the network station system in the city of Semarang regarding making decisions about the targets and objectives of broadcasting programs, identifying and targeting audiences, establishing policies or rules for determining the strategy to be chosen, deciding which strategy to use, strategic planning on television stations is very necessary so that the objectives of broadcast planning can be achieved. In the end, a deeper study is needed from both the empirical and literary aspects to find out more about the media strategy in dealing with the network station system.
\end{abstract}

Keywords: Media Policy, Critical Theory, Network TV Stations

\section{Pendahuluan}

Kebijakan Sistem Stasiun Jaringan (SSJ) pada dasarnya berangkat dari semangat otonomi daerah dan desentralisasi, sebagai usaha demokratisasi di bidang Penyiaran. Selama bertahun-tahun, Indonesia menerapkan sistem penyiaran televisi secara terpusat (sentralisasi), di mana sejumlah Stasiun televisi yang berlokasi di Jakarta mendapat hak untuk melakukan siaran secara Nasional. Sistem penyiaran terpusat dinilai tidak adil dalam suatu negara demokratis karena tidak memberi peluang kepada masyarakat daerahnya sendiri. Sistem penyiaran tersentralisasi ini menurut Ade Armando juga mengandung banyak masalah. Ada sepuluh stasiun televisi di Jakarta yang dapat bersiaran secara nasional dengan hanya menggunakan stasiun-stasiun relai/transmitter di setiap daerah. Dalam sistem ini, siaran sepenuhnya disiapkan, dibuat, dan dipancarkan dari Jakarta menuju rumah-rumah penduduk di seluruh Indonesia dengan hanya diperantarai stasiun relai di setiap daerah tersebut. Dengan demikian, apa yang 
Jurnal Teknologi Informasi dan Komunikasi, ISSN : 2087-0868, Volume 12, Nomor 1, September 2021, Strategi Media Mnc Group Dan Kompas Gramedia Group Dalam Menghadapi Sistem Stasiun Jaringan Di Kota Semarang.

disaksikan oleh masyarakat di seluruh Indonesia sepenuhnya ditentukan oleh segenap stasiun yang berlokasi di Jakarta. Kondisi tersebut menurut Ade Armando menimbulkan dampak sangat serius dan sangat merugikan bagi masyarakat dan perkembangan ekonomi-politik-budaya daerah di luar Jakarta.

Sistem media tersentralisasi juga memiliki dampak sosial dan budaya. Seperti yang disampaikan Triyono Lukmantoro dalam Tempo interaktif, bahwa selama ini masyarakat di tingkat lokal selalu dipaksa untuk melihat tontonan gaya hidup dan persoalan-persoalan di Ibu Kota Jakarta. Triyono menyatakan, media massa seharusnya bisa memanfaatkan berbagai potensi lokal yang ada. "Jangan hanya kiblat di Jakarta". Memang bila kita perhatikan, content media televisi Nasional saat ini tidak berpihak pada lokalitas dan keberagaman. Gaya hidup yang ditampilkan sepenuhnya adalah gaya hidup Jakarta. Program yang disajikan adalah yang sesuai dengan standard norma dan nilai Jakarta. Bahkan sampai aspek bahasa, gaya bicara Jakarta saat ini menjadi rujukan remaja di seluruh Indonesia. Begitu pula dari sisi sosial, sistem sentralisasi siaran ini menurut Ade Armando tak sensitive dengan perbedaan kondisi sosial. Muatan stasiun televisi swasta diarahkan untuk menarik penonton yang cukup kaya untuk membeli barangbarang yang diiklankan di kota-kota besar. Siaran baik program maupun iklan, dari Jakarta dipancarkan ke seluruh Indonesia, padahal masyarakat di seluruh Indonesia tentunya memiliki tingkat ekonomi yang sangat beragam. Semua persoalan-persoalan tersebutlah yang kemudian mendorong perlunya desentralisasi di dunia Penyiaran.

Kompleksnya industri media massa mengakibatkan adanya konsentrasi kepemilikan media menjadi suatu proses yang tidak dapat dihindarkan oleh setiap pelaku industri media massa untuk tetap dapat berproses sebagai sebuah institusi sosial dan ekonomi. Konsentrasi kepemilikan media tersebut mempengaruhi apa yang terjadi di pasar media massa, misalnya apa yang dilakukan oleh media tertentu akan menentukan tindakan yang diambil oleh media lain dan juga berpengaruh terhadap masyarakat itu sendiri. Konsentrasi kepemilikan media ini ini bukanlah semata-mata fenomena bisnis, melainkan fenomena ekonomipolitik yang melibatkan kekuasaan. PT Media Nusantara Cipta (PT MNC Terbuka) merupakan salah satu konglomerasi media terbesar di Indonesia. Perusahaan media ini memiliki bisnis di bidang produksi program, distribusi program, saluran televisi terrestrial, saluran program televisi, surat kabar, tabloid dan jaringan radio. Perusahaan ini boleh dikatakan sebagai perusahaan media yang terintegrasi secara raksasa.
Sedangkan Kelompok Kompas Gramedia adalah salah satu perusahaan di Indonesia yang bergerak di bidang media massa yang didirikan pada tanggal 28 Juni 1965 oleh PK Ojong dan Jakob Oetama. Pada tahun 1980- an usaha mereka mulai dikembangkan, terutama dalam bidang komunikasi. KG memiliki beberapa anak perusahaan atau bisnis unit yang bervariatif dari media massa, toko buku, percetakan, radio, hotel, lembaga pendidikan, event organizer, stasiun TV hingga Universitas. Pada tahun 2005, perusahaan ini mempekerjakan sekitar 12.000 karyawan yang tersebar di seluruh Indonesia. Saat ini, K K G terbagi atas beberapa anak perusahaan, yaitu: Surat kabar yang berbasis nasional (Kompas) dan daerah (Tribun), Warta Kota, Harian Surya. Majalah (National Geographic, Hai, bobo, kawanku, chip, info komputer, angkasa, what hifi\& home cinema, hot game, idea). Tabloid (nova, sedap, saji, PC Plus, Bola, Soccer, motorplus). Media online (Kompas.com), tribunnews.com, Kompas e-paper yaitu bentuk digital dari harian Kompas. Radio (Sonora), selain bergerak dibidang media, KKG juga memiliki Jaringan percetakan (PT Gramedia Printing Group: (Palmerah, Cikarang, Bandung, Bali), PT Bawen Media Tama (Semarang), PT Medan Media Grafika Tama (Medan), PT Rambang (Palembang), PT Antar Surya Jaya (Surabaya). Jaringan Penerbit Buku (Gramedia Pustaka Utama, Elex Media Komputindo, Penerbit Buku Kompas, Kepustakaan Populer Gramedia, Gramedia Widiasarana Indonesia ). Jaringan toko buku (Gramedia). Jaringan hotel (Amaris, Santika, Kayana). Event organizer (Dyandra Promosindo). Industri (PT Graha Kerindo Utama yang memproduksi tissue Tessa) dan dalam bidang pendidikan (Universitas Multimedia Nusantara dan ELTI Gramedia (English Language Training International).

Kendala yang dihadapi oleh Sistem Stasiun Jaringan saat ini di Jawa Tengah adalah akibat dari sistem sentralisasi ini menghasilkan ketidakadilan ekonomi, politik, dan budaya. Secara ekonomi, ratusan miliar bahkan triliunan rupiah belanja iklan televisi beredar di Jakarta. Rumah produksi dan industri iklan sebagian besar tumbuh di Jakarta. Hasilnya, lapangan pekerjaan di industri televisi hanya berkembang sehat di Jakarta. Lapangan pekerjaan di daerah hanya tersedia stasiun TV lokal yang merana secara bisnis atau pekerjaan sebagai kontributor stasiun TV Jakarta dengan kesejahteraan rendah. Secara politik, apa yang terjadi di stasiun TV Jakarta bersiaran nasional kurang lebih sama. Banyak daerah di berbagai belahan Indonesia tidak mendapat peliputan media yang memadai saat terjadi Pemilukada, misalnya. Di sebagian besar tempat, televisi tidak hadir bagi publik yang membutuhkan informasi memadai dalam kontestasi demokrasi. Berita-berita dari daerah luar Jakarta 
mengenai politik, ekonomi, dan budaya lokal yang disetorkan kontributor harus bersaing dengan berbagai berita "nasional" yang asalnya dari Jakarta. Pada saat bersamaan, budaya metropolitan merembes ke berbagai belahan bumi Indonesai seolah tanpa filter. Gaya hidup sinetron dan selebritas yang semuanya berlatar belakang metropolitan Jakarta, mendesak budaya lokal ke sudut terjauh dari ruang publik kita. Alhasil, sentralisasi membunuh fungsi media sebagai ruang publik. Kemauan stasiun televisi memperbanyak konten lokal.

Menjadi menarik untuk mencoba mengungkap lebih dalam bagaimana problematika penyiaran sistem stasiun berjaringan, dan mengamati di lapangan sejauh mana implementasinya hingga saat ini. Salah satunya adalah kota Semarang. Menarik untuk mengamati kebijakan SSJ di kota Semarang karena selain sebagai ibukota provinsi, selama ini Semarang menjadi salah satu kota yang dijadikan objek penghitungan rating oleh AC Nielsen. dan sebagainya.

\section{Metode Penelitian}

Pendekatan yang digunakan dalam penelitian ini adalah pendekatan deskriptif kualitatif. Pendekatan ini dipakai karena peneliti bermaksud memperoleh gambaran yang mendalam tentang strategi media MNC TV dan KOMPAS TV JATENG dalam menghadapi kebijakan SSJ dalam regulasi penyiaran dan dinamika yang melingkupinya. Pada pendekatan ini, peneliti membuat suatu gambaran kompleks, meneliti katakata, laporan terinci dari pandangan responden, dan melakukan studi pada situasi yang alami sehingga dapat menghasilkan data deskriptif berupa kata-kata tertulis maupun lisan dari orang-orang dan perilaku yang diamati.

Metoda yang digunakan dalam penelitian ini adalah Studi Kasus dengan jenis studi kasus jamak dengan Multi level analysis karena obyek dalam penelitian ini terdiri dari berbagai kelompok yang berbeda, serta bermaksud menyoroti berbagai tingkatan masalah penting yaitu: kondisi makro industri media dan regulasinya di Indonesia, dinamika dalam implementasi SSJ, serta strategi dan kebijakan media yang berkepentingan dalam SSJ.

\section{Hasil dan Pembahasan}

Kondisi beratnya persaingan industri televisi lokal dengan televise nasional pada dasarnya sudah dipahami oleh pemerintah dan para pembuat kebijakan penyiaran. Karenanya dalam UU Penyiaran, semangat menghidupkan televisi lokal diatur melalui Sistem Stasiun Jaringan (SSJ).
Spirit dasar dari siaran berjaringan yaitu terpenuhinya aspek penyebaran kepemilikan (diversity of ownership), keberagaman isi atau program siaran (diversity of content), dan kearifan lokal. Dalam format penyiaran itu, maka tidak akan terjadi head to head antara TV Jakarta yang bersiaran nasional dan TV lokal yang bersiaran terbatas. Sebaliknya didorong bentuk kemitraan yang diharapkan dapat menghidupkan televisi lokal dan menciptakan keadilan merata di industri penyiaran televisi. Namun sudah hampir 10 tahun sejak UU 32/2002 tentang penyiaran diterbitkan, realisasi dari pelaksanaan sistem televisi berjaringan di Indonesia, masih jauh dari harapan. Implementasinya sepertinya berhenti di idealisme, karena yang terjadi justru sebaliknya. Televisi nasional justru terus mencari celah perundangundangan untuk kepentingan bisnisnya, sehingga sampai saat ini implementasi kebijakan SSJ masih sebatas kamuflase. Bagian pemasaran (sales marketing) memegang peranan penting dalam mendorong kemajuan media penyiaran, bahkan berperan sangat menentukan dalam kelangsungan hidup media penyiaran komersial. Sukses atau gagalnya departemen pemasaran dalam menjalankan fungsinya akan menentukan apakah suatu stasiun penyiaran akan tetap mengudara atau tenggelam. Media penyiaran adalah tempat untuk beriklan, pemasaran waktu siaran (airtime) merupakan sumber pendapatan utama bagi media penyiaran. Target kerja setiap media penyiaran ialah mampu membayar setiap tagihan dan sekaligus mendapat keuntungan dari kegiatannya. Departemen pemasaran bertanggung jawab menjual waktu siaran kepada para pemasang iklan. Program yang berhasil menarik audien, khususnya audien yang diinginkan pemasang iklan mampu memberikan

pendapatan bagi media penyiaran bersangkutan. Semakin besar pendapatan yang diperoleh, semakin besar dana yang tersedia untuk memproduksi atau membeli program yang lebih baik. Enam faktor yang mempengaruhi harga waktu siaran iklan yaitu:

a. Ukuran atau Jumlah Audien

Ukuran atau jumlah audien merupakan faktor yang selalu berubah-ubah. Terkait dengan jumlah audien yang selalu berubah-ubah terdapat beberapa faktor yang mempengaruhi tarif siaran iklan televisi berdasarkan besar kecilnya audien yang ada pada waktu (segmen) siaran tertentu yaitu waktu penayangan, rating acara dan faktor lain.

b.Waktu Penayangan

Faktor yang sangat penting dalam menentukan tarif siaran iklan adalah terkait dengan waktu suatu iklan akan disiarkan, yaitu pukul berapa suatu iklan itu ditayangkan setiap harinya. Waktu siaran adalah 24 jam sehari semalam yang terbagi-bagi dalam beberapa segmen siaran (day parts) dan setiap segmen memiliki jumlah audien yang berbeda-beda. 
Jumlah audien terbesar penonton televisi terjadi pada saat prime time atau waktu utama. Pada saat prime time ini biasanya stasiun televisi mengenakan tarif iklan yang paling mahal (premium). Secara umum pembagian segmen siaran selain waktu utama, adalah waktu siaran pagi hari, siang, petang dan saat menjelang waktu utama, tengah malam dan dini hari. Kapan awal dan akhir suatu segmen tidak selalu sama antara stasiun televisi, begitu pula dalam hal penentuan waktu utama. Setiap stasiun siaran memiliki ketentuan mengenai pembagian waktu siaran yang tidak selalu persis sama.

c. Rating Acara

Popularitas suatu acara, ketika suatu iklan akan ditayangkan merupakan faktor yang sangat penting dalam menentukan tarif iklan. Laporan rating yang dikeluarkan secara teratur (reguler) biasanya hanya dilakukan terhadap stasiun televisi nasoinal atau stasiun jaringan (network) yang melakukan siaran secara nasional, sedangkan penelitian rating acara terhadap stasiun televisi lokal hanya dilakukan pada saat-saat tertentu saja.

d. Ukuran Pasar

Adapun yang dimaksud dengan ukuran pasar (market size) adalah seberapa banyak audien yang terdapat pada suatu wilayah siaran. Misalnya suatu stasiun televisi lokal yang mendapat ijin beroperasi di Semarang, maka stasiun itu memiliki market size sebanyak penduduk yang berada di Semarang. Semakin besar penduduk di suatu wilayah maka biaya iklan akan semakin mahal.

e. Fasilitas Stasiun

Sedangkan mengenai fasilitas stasiun yang dimaksud dengan hal itu adalah terkait dengan frekuensi, daya, lokasi antena pemancar dan faktorfaktor teknis lainnya yang mempengaruhi daya jangkau siaran. Hal ini berarti suatu stasiun penyiaran yang beroperasi di suatu daerah tertentu, tidak selalu berarti memiliki daya jangkau siaran yang sama dengan luas wilayah daerah bersangkutan. Semakin luas daya jangkau siaran suatu stasiun penyiaran, maka tarif iklannya semakin tinggi.

f. Afiliasi Jaringan

Afiliasi jaringan berarti, seberapa besar suatu stasiun berjaringan dengan stasiun lainnya. Untuk televisi jaringan ditentukan oleh seberapa banyak stasiun bersangkutan memiliki afiliasi dengan televisi daerah. Semakin besar suatu stasiun penyiaran memiliki jaringan maka semakin mahal pula biaya iklan pada stasiun itu. Sejak bergulirnya UU nomor 32 Tahun 2002 tentang penyiaran, dunia penyiaran di Indonesia mengalami perubahan yang berarti. Pertumbuhan penyiaran radio dan televisi baik di kota maupun di daerah meningkat sangat pesat. Adanya regulasi tersebut menjadi payung bagi eksistensi televisi lokal, sehingga memicu lahir dan tumbuhkembangnya TV lokal di berbagai daerah di
Indonesia. Tahun 2004 jumlah TV lokal di Indonesia berada pada kisaran 50 stasiun. Saat ini TV lokal telah menembus lebih dari 200 stasiun. Jumlah ini masih terus berkembang seiring pembukaan loket perizinan di berbagai daerah.

\section{Simpulan}

Tulisan ini bertujuan untuk mengargumentasikan Siaran adalah mata acara atau rangkaian mata acara berupa pesanpesan dalam bentuk suara, gambar, atau suatu gambar yang dapat didengar atau dilihat oleh khalayak dengan pesawat penerima radio atau televise dengan atau tanpa alat bantu. Siaran berasal dari kata "siar". Siar berarti menyebarkan informasi melalui pemancar. Kata "siar" ditambah "an" membentuk kata benda, yang memiliki makna apa yang disiarkan.

Sedangkan penyiaran sendiri menurut J.B. Wahyudi adalah proses penyelenggaraan siaran atau kegiatan pemancarluasan siaran melalui sarana pemancar atau sarana, tranmisi didarat, dilaut, atau diantariksa dengan menggunakan spectrum frekuensi radio melalui udara, kabel, dan atau media lainnya untuk dapat diterima secara serentak dan bersamaan oleh masyarakat dengan perangkat penerima siaran.

Menurut Wahyudi, Penyiaran adalah kegiatan pembuatan dan proses menyiarkan acara radio dan televisi serta pengelolaan operasional perangkat lunak dan keras, yang meliputi segi idiil, kelembagaan dan sumber daya manusia untuk memungkinkan terselenggaranya siaran radio dan televise. Sesuai dengan obyek penelitian ini, maka peneliti akan lebih fokus pada media televisi.

Secara normatif, siaran televisi mampu menyajikan menu kepada masyarakat tanpa harus mendatangi, tidak membedakan status, kasta, golongan, dan usia selama 24 jam nonstop. Ini berarti televisi tidak dibatasi waktu hari, minggu, dan bulan. Melainkan hanya dibatasi waktu detik, menit, dan jam. Begitu juga, televisi pendidikan yang sementara ini digagas oleh pembuat kebijakan pendidikan oleh elit pusat dimaksudkan sebagai upaya pengkomunikasian informasi, mendidik, dan juga transfer of knowledge, khususnya di wilayahwilayah pedalaman. Namun demikian, yang menjadi permasalahan di kemudian hari adalah tv bukan lagi hanya wilayah-wilayah marginal saja yang perlu untuk mendapatkan acara televisi pendidikan, melainkan daerah-daerah yang dianggap lebih berkembangpun layak menikmati menu tv pendidikan.

Penyiaran televisi adalah media komunikasi massa dengar pandang, yang menyalurkan gagasan dan informasi dalam bentuk suara dan gambar secara umum, baik terbuka maupun tertutup, berupa program yang teratur dan berkesinambungan. Dalam 
penelitian ini yang dimaksudkan adalah siaran televisi yaitu MNC TV dan KOMPAS TV JATENG. Televisi dipahami sebagai televisi siaran yang dilakukan melalui tranmisi atau kabel, yang mana televisi siaran akan menghasilkan siaran televisi (berupa audio visual) yang ditangkap oleh medium atau perangkat televisi.

Proses penyelenggaraan siaran merupakan proses yang panjang dan rumit, yang harus berjalan diatas landasan pola pikir dan tindakan yang cepat atau dinamis, praktis dan berkualitas16. Oleh sebab itu para penyelenggara penyiaran televisi harus bisa menayangkan program-program acara yang berkualitas dan mempunyai bobot kepada para pemirsanya, terlebih dari itu sesuai dengan norma, etika dan estetika yang berlaku.

Siaran sebagai output organisasi penyiaran adalah benda abstrak yang sangat potensial untuk dipergunakan mencapai tujuan yang diharapkan. Siaran merupakan hasil perpaduan antara kreatifitas manusia dan kemampuan sarana/alat, atau antara perangkat keras dan perangkat lunak. Perangakat keras terdiri dari17:

a. Sarana dan prasarana

b. Pemancar dan perangkatnya

Sedangkan perangkat lunak, terdiri dari:

a. Manusia dan pengelolaan (yang didalamnya termasuk manajemen)

b. Program acara

Siaran yang berupa program acara memiliki daya pengaruh sangat kuat bagi individu atau kelompok, akibatnya siaran televisi dapat menimbulkan dampak luas di masyarakat. Program acara yang disiarkan sangat tergantung dari orangorang didalam organisasi penyiaran, oleh karena itu setiap program acara yang disiarkan haruslah benarbenar direncanakan, diproduksi, dan disajikan kepada khalayak dengan isi pesan yang bersifat informatif, edukatif, persuasif, stimulatif, dan komunikatif. Dengan kata lain peranan perencanaan sangat penting di dalam proses penyelenggaraan siaran televisi (television is planning). Eksistensi televisi sebagai media komunikasi pada prinsipnya, bertujuan untuk dapat menginformasikan segala bentuk acaranya kepada masyarakat luas. Hendaknya, televisi mempunyai kewajiban moral untuk ikut serta berpartisipasi dalam menginformasikan, mendidik, dan menghibur masyarakat yang pada gilirannya berdampak pada perkembangan pendidikan masyarakat melalui tanyangan-tayangan yang disiarkannya.

\section{Daftar Pustaka:}

Armando Ade. Televisi Jakarta Di Atas Indonesia. 2011. Yogyakarta: Bentang Pustaka

Armando Ade. "Televisi Indonesia di Bawah Kapitalisme Global”. 2016. Jakarta: Kompas Media Nusantara

Rianto Puji. "Dominasi TV Swasta (Nasional) Tergerusnya Keberagaman Isi dan Kepemilikan”. 2012. Yogyakarta: PR2MediaYayasan Tifa

Salim Agus. "Teori dan Paradigma Penelitian Sosial (dari Denzin Guba dan penerapannya)”. 2001 Yogyakarta: PT Tiara Wacana Yogya.

Tesis B. Nugroho Sekundatmo, "Kontestasi Negara, Industri dan masyarakat sipil dalam kontroversi peraturan pemerintah tentang penyiaran". Universitas Indonesia.2006

Primasanti. "Studi Eksplorasi Sistem Siaran Televisi Berjaringan di Indonesia”.

Nuruddin. "Pengantar Komunikasi Massa”.2007. Jakarta: Rajawali Pers

J.B. Wahyudi." Dasar-Dasar Manajemen Penyiaran”. 1994. Jakarta: Gramedia Pustaka Utama

Morissan M.A." Manajemen Media Penyiaran". 2008.Jakarta: Prenada Media Group.

UU penyiaran No.32 tahun 2002 tentang Penyiaran

Komisi Penyiaran Indonesia. Apresiasi KPID Jateng 2017.

Web

http://www.kpi.go.id/index.php/id/umum/38dalam-negeri/33955-apresiasi-kpid-jateng2017 diakses 28 November 2017 pukul 14.35 http://kpid.jatengprov.go.id/ 